Reviu Akuntansi dan Bisnis Indonesia, Vol. 3 No. 2, Hlm: 190-205, Desember 2019

Website: http://journal.umy.ac.id/index.php/rab

\title{
Pengaruh Karakteristik Perusahaan Terhadap Nilai Perusahaan dengan Perataan Laba Sebagai Variabel Intervening Pada Perusahaan Manufaktur yang Terdaftar di BEI 2014-2018
}

\author{
Lestari Adhi Widyowati * Inta Hartaningtyas Rani \\ Program Studi Akuntansi Institut Teknologi dan Bisnis Ahmad Dahlan Jakarta
}

I N F O A R T I K E L

Kata Kunci:

ROA, DER, Ukuran

Perusahaan, Perataan Laba,

Nilai Perusahaan.

Jenis Artikel:

Penelitian Empiris

Correspondence:

lestariadhi1202@gmail.com

\author{
A B S T R A K
}

Perusahaan manufaktur termasuk emiten terbesar dari seluruh perusahaan yang listing di BEI. Hal ini memberikan kesempatan bagi para pelaku pasar atau investor untuk berinvestasi pada industri ini. Tindakan perataan laba merupakan bentuk manipulasi laba yang mungkin dilakukan oleh manajer untuk mengurangi fluktuasi laba perusahaan, sehingga diharapkan kinerja perusahaan akan terlihat bagus dan investor akan lebih mudah memprediksi laba masa depan. Akuntansi adalah penyedia informasi berupa laporan keuangan kepada pihak internal dan ekternal perusahaan yang berguna sebagai sarana pengambilan keputusan, namun dengan adanya kemungkinan perataan laba akan mengakibatkan laporan keuangan tidak lagi mencerminkan keadaan perusahaan yang sebernarnya dan dapat menyesatkan investor dalam pengambilan keputusan sehingga pada akhirnya dapat mempengaruhi nilai perusahaan tersebut. Menjadi menarik untuk diteliti lebih dalam mengenai adanya hubungan antara karakteristik perusahaan dengan nilai perusahaan di mana perataan laba menjadi variabel penengah yang mempengaruhi hubungan tersebut.

Penelitian ini menggunakan pengujian hipotesis dengan jumlah observasi yang digunakan adalah 670 observasi. Metode yang digunakan adalah purposive sampling. Jenis data adalah data sekunder yang bersumber dari laporan tahunan dan laporan keuangan. Pengujian hipotesis dilakukan dengan analisis jalur dengan alat bantu statistik Software SPSS versi 20.0 Hasil Penelitian ini menunjukan bahwa ROA berpengaruh negatif terhadap perataan laba, DER berpengaruh negatif terhadap perataan laba, ukuran perusahaan berpengaruh negatif terhadap perataan laba, ROA berpengaruh positif terhadap nilai perusahaan, DER berpengaruh positif terhadap nilai perusahaan, ukuran perusahaan berpengaruh negatif terhadap nilai perusahaan.

(C) 2019 RAB. Published by Universitas Muhammadiyah Yogyakarta

\section{PENDAHULUAN}

Dalam mendirikan suatu perusahaan, tentunya ada target-target yang ingin dipenuhi oleh pendiri perusahaan tersebut. Tujuan didirikannya perusahaan tersebut antara lain adalah mencapai keuntungan maksimal, memakmurkan pemilik, atau memaksimalkan nilai dari perusahaan tersebut. Inti dari tujuan tersebut sebenarnya tidak terlalu berbeda, hanya saja ada perbedaan 
penekanan apa yang ingin dicapai antara satu tujuan dengan tujuan yang lain. Salah satu cara mengukur nilai perusahaan adalah dengan melihat nilai harga saham.

Selama tahun 2014 sampai dengan 2018 jumlah emiten yang ada pada industri sebanyak 144 perusahaan angka ini menunjukan bahwa perusahaan manufaktur mendominasi perusahaan yang terdaftar di BEI. Perusahaan manufaktur sebagai emiten terbesar mempunyai peluang yang besar dalam memberikan kesempatan bagi para pelaku pasar atau investor untuk berinvestasi. Hal ini menjadikan perusahaan manufaktur selalu mendapatkan perhatian dan sorotan para pelaku pasar. Harga saham disana mengalami perubahan yang cukup dinamis. Saham-sahamnya banyak yang aktif diperjualbelikan dipasar sekunder. Pengumuman laba perusahaan juga merupakan informasi penting yang mencerminkan nilai perusahaan bagi pelaku pasar. Dari informasi yang diberikan perusahaan tersebut maka pelaku pasar akan melakukan prediksi dan menentukan keputusan investasi. Perubahan harga yang dinamis dan tingkat kompleksitas yang tinggi dalam kegiatan perusahaan bisa membuka peluang bagi pihak manajemen untuk melakukan pengelolaan atas laba dengan melakukan income smoothing.

Pentingnya informasi laba untuk pengambilan keputusan disadari oleh manajemen sehingga manajemen cenderung melakukan dysfunctional behavior(perilaku tidak semestinya) yang dipengaruhi oleh adanya asimetris informasi dalam konsep teori keagenan dimana tiap pihak-pihak baik principal selaku pemegang saham maupun agent selaku manajemen perusahaan mempunyai perbedaaan kepentingan dan ingin memperjuangkan kepentingan pribadi mereka masing-masing, sehingga mendorong manajer untuk melakukan manajemen laba atau manipulasi atas laba yang diperoleh. Perataan laba merupakan salah satu bentuk manipulasi laba yang dilakukan oleh manajer untuk mengurangi fluktuasi laba perusahaan, sehingga diharapkan kinerja perusahaan akan terlihat bagus dan investor akan lebih mudah memprediksi laba masa depan.

Fenomena perataan laba di Indonesia pernah terjadi adalah pada PT Kimia Farma adalah salah satu produsen obat-obatan milik pemerintah di Indonesia. Pada audit tanggal 31 Desember 2001, manajemen Kimia Farma melaporkan adanya laba bersih sebesar Rp 132 milyar, dan laporan tersebut di audit oleh Hans Tuanakotta \& Mustofa (HTM). Akan tetapi, Kementerian BUMN dan Bapepam menilai bahwa laba bersih tersebut terlalu besar dan mengandung unsur rekayasa. Setelah dilakukan audit ulang, pada 3 Oktober 2002 laporan keuangan Kimia Farma 2001 disajikan kembali (restated), karena telah ditemukan kesalahan yang cukup mendasar.

Penelitian yang berkaitan dengan perataan laba telah banyak dilakukan dan memberikan hasil yang beragam, seperti penelitian pada pengaruh Company Size, Financial Leverage dan Profitability terhadap Income Smoothing pada perusahaan Property and Real Estate yang dilakukan oleh Adisti (2012) menunjukan hasil bahwa secara bersama-sama variabel company size, financial leverage dan profitability berpengaruh terhadap income smoothing. Secara parsial, variabel company size, dan debt to total equity berpengaruh positif terhadap income smoothing dan variabel debt to total asset berpengaruh negatif terhadap income smoothing. Sedangkan variabel return on asset, return on equity dan net profit margin tidak berpengaruh terhadap income smoothing.

Fatmawati dan Atik (2015) juga melakukan penelitian pada analisis pengaruh ukuran perusahaan, profitabilitas, dan financial leverage terhadap praktik perataan laba pada perusahaan Manufaktur yang memproksikan profitabilitas pada return on asset dan financial leverage pada debt to total asset. Hasil penelitian ini menunjukan variabel ukuran perusahaan, profitabilitas dan financial leverage secara bersama-sama berpengaruh secara signifikan terhadap perataan laba. Secara parsial, ukuran perusahaan berpengaruh negatif terhadap perataan laba sedangkan variabel profitabilitas dan financial leverage berpengaruh positif terhadap perataan laba.

Dalam penelitian ini, penulis mengambil riset yang dijadikan patokan, yaitu penelitian yang dilakukan oleh Mona Yulia (2013). Penelitian tersebut membahas tentang pengaruh karakteristik perusahaan dan nilai saham terhadap tindakan perataan laba. Dari hasil penelitian tersebut menyatakan bahwa karakteristik perusahaan yang diproksikan dengan ukuran perusahaan(LnTA) berpengaruh positif terhadap perataan laba, profitabilitas (ROA)berpengaruh positif terhadap perataan laba, leverage berpengaruh signifikan terhadap tindakan perataan laba, nilai saham berpengaruh negatif terhadap tindakan perataan laba. Terdapat perbedaan penelitian, dalam penelitian ini penulis menambahkan pengaruh antara tindakan perataan laba dengan nilai 
perusahaan serta menggunakan proksi karakteristik perusahaan yaitu ukuran perusahaan (LnTotal Penjualan), profitabilitas (ROA) dan leverage (DER).

Untuk melanjutkan sekaligus melengkapi penelitian yang telah ada tersebut, kami memilih variabel perataan laba sebagai variable intervening yang belum pernah digunakan sebelumnya pada penelitian terdahulu. Dalam penelitian ini akan dikaji lebih dalam mengenai adanya hubungan antara karakteristik perusahaan dengan nilai perusahaan di mana perataan laba menjadi variabel penengah yang mempengaruhi hubungan tersebut

\section{TINJAUAN LITERATUR DAN PERUMUSAN HIPOTESIS}

\section{Relevansi Nilai Informasi Akuntansi}

Beaver (dalam Puspitaningtyas,2012) memberikan definisi relevansi nilai informasi akuntansi sebagai kemampuan menjelaskan (explanatory power) nilai suatu perusahaan berdasarkan informasi akuntansi (Barth et al, 2009) mengemukakan bahwa informasi akuntansi dikatakan relevan jika informasi tersebut memiliki hubungan yang positif dan signifikan dengan harga saham, informasi akuntansi memiliki relevansi nilai jika informasi tersebut mampu memprediksi atau mempengaruhi harga saham, sehingga dapat dijadikan informasi yang bermanfaat bagi pengambil keputusan. Ball dan Brown (dalam Puspitaningtyas,2012) membuktikan bahwa informasi akuntansi bermanfaat bagi investor untuk mengestimasi nilai yang diharapkan (expected value) dari tingkat return dan tingkat resiko dari sekuritas. Analisis informasi akuntansi dapat bermanfaat bagi investor untuk memprediksi resiko investasi saham suatu perusahaan, seperti diungkapkan oleh Hartoni (2008).

Nilai Perusahaan (Value of The Firm)

Nilai perusahaan berhubungan erat dengan kemampuan perusahaan untuk meningkatkan kemakmuran pemegang sahamnya. Nilai perusahaan merupakan persepsi investor terhadap tingkat keberhasilan perusahaan, yang sering dikaitkan dengan harga sahamnya. Harga saham menurut H.M Jogiyanto (2000) adalah harga saham yang terjadi dipasar bursa pada saat tertentu yang ditentukan oleh pelaku pasar dan ditentukan oleh permintaan dan penawaran saham yang bersangkutan dipasar modal. Bagi perusahaan yang menjual sahamnya ke masyarakat (go public) indikator nilai perusahaan adalah harga saham yang diperjualbelikan di bursa efek.

Teori Sinyal (Signalling Theory)

Menurut Jama'an (2008) signaling theory mengemukakan tentang bagaimana seharusnya sebuah perusahaan memberikan sinyal kepada pengguna laporan keuangan. Sinyal ini berupa informasi mengenai apa yang sudah dilakukan oleh manajemen untuk merealisasikan keinginan pemilik. Sinyal dapat berupa promosi atau informasi lain yang menyatakan bahwa perusahaan tersebut lebih baik daripada perusahaan lain. Teori sinyal menjelaskan bahwa pemberian sinyal dilakukan oleh manajer untuk mengurangi asimetris informasi. Manajer memberikan informasi melalui laporan keuangan bahwa menerapkan kebijakan akuntansi konservatisme yang menghasilkan laba yang lebih berkualitas karena prinsip ini mencegah perusahaan melakukan tindakan membesar-besarkan laba dan membantu pengguna laporan keuangan dengan menyajikan laba dan aktiva yang tidak overstate.

Teori keagenan (Agency Theory)

Teori agensi adalah hubungan atas kontrak mitra principal dan agent. Teori agensi memiliki asumsi bahwa tiap-tiap individu semata-mata termotivasi oleh kepentingan dirinya sendiri sehingga menimbulkan konflik kepentingan antara principal dan agen. Dalam konteks perusahaan, yang 
dimaksud dengan principal adalah pemegang saham, sedangkan agen adalah manajemen yang mengelola perusahaan (Budiasih,2009). Dalam kaitannya dengan keagenan, manajemen memiliki lebih banyak informasi internal perusahaan dibandingkan dengan principal, sehingga memungkinkan agen untuk memaksimalkan pemenuhan kepentingan pribadinya dengan cara illegal yaitu moral hazard dan adverse selection (Hendrikson dan Breda,2000) dalam (Harris Prasetya, Shiddiq Nur Raharjo). Moral Hazard dapat disebut juga sebagai perilaku menyimpang dari kontrak kerja, sedangkan adverse selection dapat disebut juga sebagai penyimpangan dari penggunaan informasi sesuai yang dikehendaki principal. Informasi akuntansi yang digunakan principal sebagai acuan untuk mengukur kinerja manajer dan juga sebagai dasar pemberian reward membuat timbulnya dysfunctional behavior dikalangan manajer dan cenderung melakukan perataan laba dengan memanipulasi informasi sedemikian rupa agar terlihat kinerja manajer terlihat bagus.

Adapun hipotesis yang akan diuji dalam penelitian ini adalah:

$\boldsymbol{H}_{I}$ : Terdapat pengaruh positif ROA, DER dan ukuran perusahaan terhadap perataan laba.

$H_{2} \quad$ : Terdapat pengaruh positif ROA terhadap perataan laba.

$\boldsymbol{H}_{3} \quad$ : Terdapat pengaruh positif DER terhadap perataan laba.

$\boldsymbol{H}_{4} \quad$ : Terdapat pengaruh positif ukuran perusahaan terhadap perataan laba.

$\boldsymbol{H}_{5} \quad$ : Terdapat pengaruh negatif perataan laba terhadap nilai perusahaan.

$\boldsymbol{H}_{6}$ : Terdapat pengaruh positif ROA, DER dan ukuran perusahaan terhadap nilai perusahaan.

$\boldsymbol{H}_{\boldsymbol{r}} \quad$ : Terdapat pengaruh positif ROA terhadap nilai perusahaan.

$\boldsymbol{H}_{3} \quad$ : Terdapat pengaruh positif DER terhadap nilai perusahaan.

$\boldsymbol{H}_{4}$ : Terdapat pengaruh positif ukuran perusahaan terhadap nilai perusahaan.

\section{METODE PENELITIAN}

Desain Penelitian

Dengan menggunakan metode kausalitas eksplanatoris peneliti mencari kausalitas antara kedua jenis variabel tersebut, dengan mediasi perataan laba yang diukur dengan menggunakan indeks Eckel. Oleh karena itu diperlukan analisis jalur regresi berganda yang disebut Path Analysis, dengan uji 2 SLS.

Waktu dan Tempat Penelitian

Penelitian ini dilaksanakan di Bursa Efek Indonesia, Jl. Jendral Sudirman Kav. 52-53, Jakarta Pusat. Waktu penelitian dimulai sejak bulan April 2019 sampai dengan September 2019.

Jenis dan Sumber Data

Jenis data yang digunakan merupakan data yang bersifat kuantitatif, berupa data angka atau bilangan yang akan diolah dengan metode statistik. Data yang digunakan merupakan data sekunder yaitu data yang diperoleh tidak dari sumber pertama berupa laporan keuangan perusahaan yang diambil dari situs www.idx.co.id. 


\section{Populasi dan Sampel Penelitian}

Populasi yang menjadi penelitian ini adalah perusahaan manufaktur go public yang terdaftar di Bursa Efek Indonesia dan menerbitkan laporan keuangan tahunan yang dipublikasikan di Bursa Efek Indonesia (BEI). Populasi dalam penelitian ini berjumlah 144 perusahaan manufaktur. Sampel merupakan sebagian atau bertindak sebagai perwakilan dari populasi sehingga hasil penelitian yang berhasil diperoleh dari sampel dapat digeneralisasi pada populasi. Teknik pengambilan sampel dengan metode purposive sampling.

Definisi Operasional dan Pengukuran Variabel

a. Variabel independen

Variabel independen dalam penelitian ini adalah profitabilitas, leverage, dan ukuran perusahaan,

\section{Profitabilitas}

Variabel ini diukur dengan rasio Return on Asset (ROA) yaitu merupakan kemampuan suatu perusahaan dalam menghasilkan keuntungan dengan aset yang dimiliki, Return on Equity (ROA) dapat dihitung dengan rumus:

$$
\text { ROA }=\frac{\text { EAT }}{\text { Total Aset }} \times 100 \%
$$

Skala pengukuran yang digunakan adalah skala rasio.

\section{Leverage}

Variabel leverage digunakan untuk mengukur kemampuan perusahaan memenuhi kewajiban keuangannya. Leverage diproksikan dengan Debt Equity Ratio (DER) yang menggambarkan resiko struktual modal, dengan membandingkan dana dari kreditur dalam bentuk utang dengan investor dalam bentuk kekayaan (Fraser dan Ormiston,2004 dalam Widana dan Yasa,2013:308).

Untuk menghitung Debt Equity Ratio digunakan rumus sebagai berikut:

$$
\text { DER }=\underline{\text { Total Hutang } \times 100 \% \text { Modal }}
$$

Skala yang digunakan untuk mengukur leverage ini adalah skala rasio.

\section{Ukuran Perusahaan}

Ukuran perusahaan merupakan skala untuk menentukan seberapa besar kecilnya perusahaan dilihat dari berbagai cara yaitu total penjualan, total aktiva, nilai pasar saham, dan lain-lain. Rumusnya adalah

\section{Ukuran Perusahaan $=$ Ln. Total Penjualan}

Skala yang digunakan skala nominal.

b. Variabel Dependen

Variabel dependen atau variabel terikat adalah variabel yang nilainya dipengaruhi oleh perilaku variabel bebas. Variabel dependen dalam penelitian ini adalah nilai perusahaan. Nilai perusahaan yang diukur dari harga sahamnya. Harga saham merupakan harga yang ditentukan oleh permintaan 
saham yang bersangkutan di pasar modal. Harga saham yang dilihat adalah harga saham penutupan pada tahun ditanggal 1 April. Pengukuran nilai perusahaan adalah sebagai berikut:

Nilai Perusahaan $=$ Harga Saham Penutupan

Skala yang digunakan skala nominal.

c. Variabel Intervening

Variabel intervening adalah variabel yang secara teoritis mempengaruhi hubungan antara variabel independen dengan variabel dependen menjadi hubungan yang tidak langsung dan tidak dapat diamati dan diukur. Variabel intervening dalam penelitian ini adalah praktek perataan laba. Perataan laba adalah teknik manajemen laba dalam hal perataan atas fluktuasi laba yang dilaporkan. Tindakan perataan laba dapat diukur dengan menggunakan indeks Eckel. Indeks Eckel membedakan antara perusahaan-perusahaan yang melakukan perataan laba dengan yang tidak melakukan perataan laba.

Rumus untuk menghitung indeks Eckel adalah sebagai berikut:

$$
\text { Indeks Perataan Laba }=\frac{\mathrm{CV} \Delta \mathrm{I}}{\mathrm{CV} \Delta \mathrm{S}}
$$

Kriteria perusahaan yang melakukan tindakan peraataan laba adalah:

a) Perusahaan dianggap melakukan tindakan perataan laba apabila indeks perataan laba lebih kecil daripada $1(\mathrm{CV} \Delta \mathrm{S}>\mathrm{CV} \Delta \mathrm{I})$

b) Perusahaan dianggap tidak melakukan tindakan perataan laba apabila indeks laba lebih besar atau sama dengan $1(\mathrm{CV} \Delta \mathrm{S}=\mathrm{CV} \Delta \mathrm{I})$.

c) Apabila Perusahaan melakukan perataan laba akan diberi nilai 1 dan perusahaan yang tidak melakukan perataan laba diberi nilai 0 .

Skala yang digunakan adalah skala nominal.

\section{HASIL DAN PEMBAHASAN}

Tabel 1 Hasil Uji Statistik Data Descriptive Statistics

\begin{tabular}{|l|l|l|l|l|l|}
\hline & N & Minimum & Maximum & Mean & Std. Deviation \\
\hline ROA & 670 & -.54847 & 138.55985 & .4379569 & 6.74043094 \\
DER & 670 & -225.04485 & 23.68932 & .4421271 & 12.68344509 \\
Sales & 670 & 91552 & 8181481867 & 223671112.47 & 521899823.161 \\
PL & 670 & .000 & 1.000 & .74328 & .437148 \\
HS & 670 & 50.00 & 4000000.00 & 17705.8388 & 202201.16841 \\
Valid N (listwise) & 670 & & & & \\
\hline
\end{tabular}

a. Return on asset (ROA) merupakan ukuran kemampuan perusahaan dalam menghasilkan laba dengan menggunakan aset yang dimilikinya. Nilai minimum dan maksimum berarti perusahaan mampu menghasilkan laba dari jumlah aktiva yang dimiki paling rendah - 0.54847 atau $-54,84$ \% dari keseluruhan jumlah saham yang dimiliki perusahaan, dan paling tinggi sejumlah 138.55985. Nilai rata-rata 0.4379569 hal ini menunjukan setiap Rp.1000 aset perusahaan akan menghasilkan laba sebesar Rp. 437,9569. Nilai Standar deviasi sebesar 6.74043094 yang lebih tinggi dari nilai rata-rata menunjukkan variasi ukuran sampel untuk variabel ROA cukup besar. 
b. Debt to total equity ratio (DER) merupakan rasio yang mengukur kemampuan perusahaan dalam melunasi hutangnya dengan modal yang dimiliki perusahaan. Nilai minimum dan maksimum berarti perusahaan mampu membiayai aktiva perusahaan dengan hutang perusahaan paling rendah sebesar -225.04 dan paling tinggi adalah 23.69. Variabel DER memiliki nilai rata-rata sebesar 0.4421. Sumber dana perusahaan banyak didanai oleh hutang daripada modal sebesar $44.21 \%$ atau rata-rata nilai variabel ini sebesar 0.4421 menunjukan setiap Rp 422,1 hutang mampu dijamin oleh Rp1000 total modal perusahaan. Nilai Standar deviasi sebesar 12,6834 yang lebih tinggi dari nilai rata-rata menunjukkan variasi ukuran sampel untuk variabel DER cukup besar.

c. Variabel ukuran perusahaan (LnSales) memiliki nilai minimum sebesar Rp. 915.520.000 dan nilai maksimum sebesar Rp. 8.181.481.867 seta memiliki nilai standar deviasi sebesar Rp.521.899.823,161 .Ukuran perusahaan memiliki nilai rata-rata sebesar Rp. 22.3671.112,47. Hal ini menunjukan bahwa kemampuan perusahaan mempunyai pertumbuhan laba melalui penjualan cukup besar.

d. Variabel perataan laba (PL) memiliki nilai minimum sebesar 0.00 dan nilai maksimum sebesar 1.00 dengan standart deviasi sebesar 0.43715 . Angka nilai rata-rata sebesar 0.7433 yang kurang dari 1 menunjukan bahwa diprediksikan perusahaan manufaktur melakukan praktek tindakan perataan laba.

e. Variabel nilai perusahaan dalam penelitian ini diporksikan dengan harga saham. Harga saham perusahaan mencerminkan nilai perusahaan dimata para investor, apabila harga saham suatu perusahaan tinggi maka nilai perusahaan dimata investor juga baik dan begitu juga sebaliknya, oleh karena itu investor harus mampu memperhatikan faktor-faktor yang mempengaruhi harga saham. Variabel nilai perusahaan (HS) memiliki nilai minimum 50 dan nilai maksimum 4.000.000 dan nilai rata-rata sebesar 17705.8388 dengan standart deviasi sebesar 202201.16841. Hal ini menunjukan rata-rata nilai pasar per lembar saham perusahaan manufaktur sebesar 17705.8388 .

Uji Normalitas P-P Plot

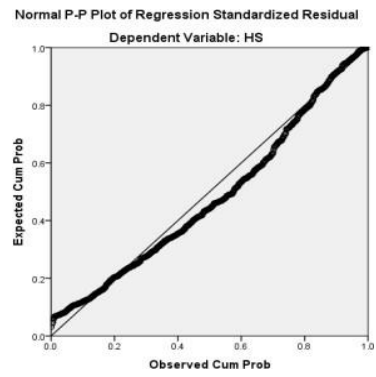

Gambar 1 Hasil Uji Normalitas P-P Plot

Dapat dilihat bahwa data menyebar disekitar garis diagonal dan mengikuti arah garis diagonal pada grafik histogram, hal ini menunjukkan bahwa pola distribusi normal. Jadi dapat disimpulkan bahwa berdasarkan grafik P-P plot, model regresi memenuhi asumsi normalitas.

Uji Multikolinearitas

Tabel 2 Hasil Uji Multikolinearitas

\begin{tabular}{|c|c|c|c|c|c|c|c|c|}
\hline \multirow{3}{*}{\multicolumn{2}{|c|}{ Model }} & \multirow{2}{*}{\multicolumn{2}{|c|}{$\begin{array}{c}\text { Un standardized } \\
\text { Coefficients }\end{array}$}} & & & & & \\
\hline & & & & \multirow{2}{*}{$\begin{array}{c}\text { Standardized } \\
\text { Coefficients } \\
\text { Beta }\end{array}$} & \multirow[t]{2}{*}{$\mathrm{t}$} & \multirow[t]{2}{*}{ Sig. } & \multicolumn{2}{|c|}{ Colline arity Statistics } \\
\hline & & $\mathrm{B}$ & Std. Error & & & & Tolerance & VIF \\
\hline \multirow{5}{*}{1} & (Constant) & 47469.042 & 56492.121 & & .840 & .401 & & \\
\hline & $\mathrm{ROA}$ & -105.416 & 1167.533 & -.004 & -.090 & 928 & 992 & 1.008 \\
\hline & DER & 16.018 & 619.032 & .001 & .028 & .979 & .997 & 1.003 \\
\hline & LN_SALES & -1531.487 & 3132.659 & -.019 & -.489 & .625 & .992 & 1.008 \\
\hline & $P L$ & -4616.475 & 17978.170 & -.010 & -257 & .797 & .995 & 1.005 \\
\hline
\end{tabular}

a. Dependent Variable: HS 
Hasil uji multikolinieritas, nampak bahwa semua variabel independen yakni ROA, DER dan ukuran perusahaan memiliki VIF dibawah dari 10 dan nilai tolerance di atas 0,1 . Serta variabel intervening yaitu perataan laba sama halnya yaitu memiliki VIF dibawah dari 10 dan nilai tolerance di atas 0,1. Menurut Ghozali (2009) menjelaskan bahwa pengujian yang dilakukan untuk mengetahui ada tidaknya multikolinieritas pada suatu model regresi adalah dengan melihat nilai tolerance dan VIF (Variance Inflation Factor).

Jika nilai tolerance $>0,10$ dan VIF $<10$, maka dapat diartikan bahwa variabel independen tidak terdapat multikolinieritas.

Uji Autokorelasi

Tabel 3 Hasil Uji Autokorelasi

\begin{tabular}{|c|c|c|c|c|c|}
\hline Mbde1 & $\bar{R}$ & R Square & $\begin{array}{|ll|}\begin{array}{l}\text { Adjusted } \\
\text { Square }\end{array} & R \\
\end{array}$ & $\begin{array}{l}\text { Std. Error of } \\
\text { the Estimate }\end{array}$ & $\begin{array}{l}\text { Durbin- } \\
\text { Watson }\end{array}$ \\
\hline 1 & $.021^{2}$ & .000 & -.006 & 202762.55614 & 2.006 \\
\hline
\end{tabular}

Berdasarkan hasil uji Durbin Watson pada model regresi diatas menghasilkan nilai sebesar 2,006, sedangkan nilai DW dengan signifikan 0.05 dan jumlah data $(\mathrm{n})=670$ dengan variabel independen $(\mathrm{k})=3$ diperoleh dl sebesar 1,86498 dan du sebesar 1.87733 . (4-du) sebesar 2,12267 dan (4-dl) sebesar 2,13502 Karena nilai DW sebesar 2,006 terletak diantara (batas atas) du $<\mathrm{d}<4$ du $(1,87733<2,006<2,12267)$ nilai koefisien autokorelasi = 0 , maka tidak ada autokorelasi.

Uji Hesterokesdasitas

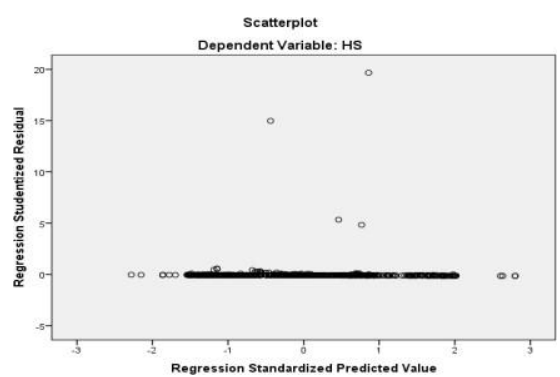

Gambar 2 Hasil Uji Hesterokesdasitas

Dari gambar diatas terlihat bahwa titik-titik menumpuk di garis nol maka data terdapat hesterokesdasitas. Namun karena dalam penelitian menggunakan analisis regresi binary logistic yang dalam penggunaanya, regresi logistik tidak memerlukan distribusi yang normal pada variabel bebasnya (variabel independen). Disamping itu, teknik analisis ini tidak memerlukan uji normalitas, uji heterokedasitas, dan uji asumsi kalsik pada variabel bebasnya (Ghozali,2011).

\section{Uji Hipotesis}

\section{Uji Hipotesis Analisis Regresi Logistic Binary}

Metode analisis yang digunakan untuk menguji hipotesis $\mathrm{H} 1$ sampai dengan $\mathrm{H} 4$ dalam penelitian ini adalah regresi binary logistic dimana variabel bebasnya merupakan kombinasi antara matrix dan non matrix (nominal, yaitu variabel dependen merupakan variabel dummy yang berskala nominal, sementara variabel independenya dapat berskala nominal, rasio, atau interval. 
Uji Hosmers and Lmeskow's Goodness of Fit

Tabel 4 Hasil Uji Hosmers and Lmeskow's Goodness of Fit

\begin{tabular}{llll}
\hline Step & Chi-square & Df & Sig. \\
\hline 1 & 8.712 & 8 & .367 \\
\hline
\end{tabular}

Dalam penelitian ini, data yang diolah menunjukan bahwa besarnya nilai signifikan Hosmer and Lmeskow's Goodness of Fit adalah 0,367 yang berarti diatas 0,05. Dengan demikian, dapat disimpulkan bahwa Ho diterima, berarti model yang dihipotesiskan fit dengan data.

Uji Omnibus Test of Model Coefficients (Uji Simultan)

Tabel 5 Hasil Uji Omnibus Test of Model Coefficients (Uji Simultan)

\begin{tabular}{lllll}
\hline & & Chi-square & Df & Sig. \\
\hline \multirow{3}{*}{ Step 1} & Step & 7.052 & 3 & .070 \\
& Block & 7.052 & 3 & .070 \\
& Model & 7.052 & 3 & .070 \\
\hline
\end{tabular}

Pengujian Hipotesis 1 : Pengaruh ROA, DER, dan ukuran perusahaan terhadap perataan laba secara simultan.

Berdasarkan hasil pengujian variabel ROA, DER, dan ukuran perusahaan memiliki nilai signifikansi sebesar 0,070 yang berarti lebih besar dari tingkat signifikansi 0,05 maka dapat disimpulkan bahwa tidak terdapat pengaruh ROA, DER, dan ukuran perusahaan terhadap perataan laba secara simultan

Uji Wald

Tabel 6 Hasil Uji Wald

\begin{tabular}{|c|c|c|c|c|c|c|c|}
\hline & & $B$ & S.E. & Wald & $d f$ & Sig. & $\operatorname{Exp}(B)$ \\
\hline \multirow{4}{*}{ Step $1^{\prime \prime}$} & $\mathrm{ROA}$ & -.012 & .012 & 1.069 & 1 & .301 & .988 \\
\hline & DER & -.071 & .037 & 3.731 & 1 & .053 & .931 \\
\hline & LN_SALES & -.035 & .036 & .983 & 1 & .321 & .985 \\
\hline & Constant & 1.761 & .625 & 7.942 & 1 & .005 & 5.818 \\
\hline
\end{tabular}

a. Variable(s) entered on step 1: ROA, DER, LN_SALES.

Pengujian Hipotesis 2 : Terdapat pengaruh positif ROA terhadap perataan laba.

Berdasarkan hasil pengujian variabel ROA terhadap perataan laba diketahui bahwa variabel ROA menunjukkan taraf signifikansi sebesar 0,301 yang berarti lebih besar dari 0,05 dan nilai $\beta$ sebesar - 0,012 maka hipotesis 2 ditolak. Penelitian ini menunjukan tidak terdapat pengaruh positif ROA terhadap perataan laba.

Pengujian Hipotesis 3: Terdapat pengaruh positif DER terhadap perataan laba.

Berdasarkan hasil pengujian DER terhadap perataan laba diketahui bahwa variabel DER menunjukan taraf signifikansi sebesar 0,053 yang berarti lebih besar dari 0,05 dan nilai $\beta$ sebesar $-0,071$, maka hipotesis 3 ditolak. Penelitian ini menunjukan tidak terdapat pengaruh positif DER terhadap perataan laba. 
Pengujian Hipotesis 4: Terdapat pengaruh positif ukuran perusahaan terhadap perataan laba.

Berdasarkan hasil pengujian variabel ukuran perusahaan (LnSales) terhadap perataan laba diketahui bahwa variabel ukuran perusahaan (LnSales) menunjukkan taraf signifikansi sebesar 0,321 yang berarti lebih besar dari 0,05 dan nilai $\beta$ sebesar -0.035 maka hipotesis 3 ditolak. Penelitian ini menunjukan tidak terdapat pengaruh positif ukuran perusahaan (lnSales) terhadap perataan laba.

Uji Negelkerke R2 Square

Tabel 7 Hasil Uji Negelkerke R2 Square

Model Summary

\begin{tabular}{|l|l|ll|ll|}
\hline Step & -2 Log likelihood & $\begin{array}{l}\text { Cox \& } \\
\text { Square }\end{array}$ & Snell & $\begin{array}{l}\text { Nagelkerke } \\
\text { Square }\end{array}$ & $R$ \\
\hline 1 & $756.204^{2}$ & .010 & & .015 \\
\hline
\end{tabular}

a. Estimation terminated at iteration number 6 because parameter estimates changed by less than .001 .

Berdasarkan tabel diatas, model summary nilai statistik -2 log likelihood sebesar 756,204 dan hasil perhitungan koefisien Negelkerke R2 Square sebesar 0,015 yang menunjukan bahwa variabel independen hanya mampu menjelaskan 1,5\% variabilitas dependen, sisanya 98,5\% dapat dijelaskan oleh faktor lain yang tidak disertakan dalam penelitian.

Uji Hipotesis Analisis Regresi Linear sederhana

Tabel 8 Hasil Uji Hipotesis Analisis Regresi Linear sederhana

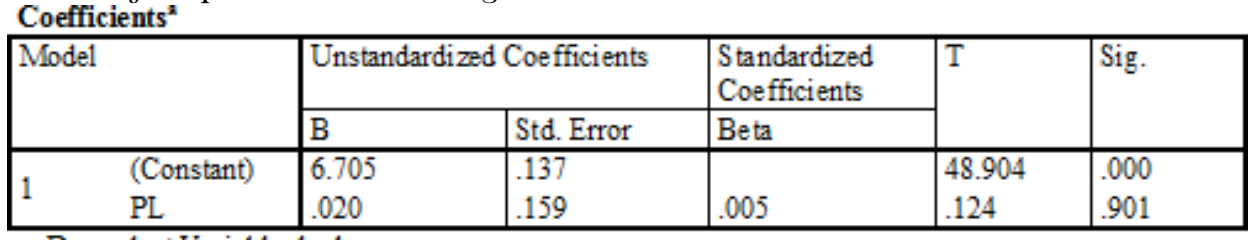

a. Dependent Variable: ln_hs

Pengujian Hipotesis 5: Pengaruh negatif perataan laba terhadap nilai perusahaan

Berdasarkan hasil pengujian variabel Perataan Laba (PL) terhadap nilai perusahaan (LnHS) menunjukan taraf signifikan sebesar 0,901 yang berarti lebih besar dari 0,05 dan nilai $\beta$ sebesar 0,020 maka hipotesis 5 ditolak. Penelitian ini menunjukan tidak terdapat pengaruh negatif perataan laba terhadap nilai perusahaan.

Uji Hipotesis Regresi Linear Berganda

Tabel 9 Hasil Uji Signifikansi Simultan (Uji F)

\begin{tabular}{|c|c|c|c|}
\hline Model & & $F$ & Sig. \\
\hline 1 & $\begin{array}{l}\text { Regression } \\
\text { Residual } \\
\text { Total }\end{array}$ & 7.408 & $.000^{\circ}$ \\
\hline
\end{tabular}


Pengujian hipotesis 6: Pengaruh ROA, DER, dan ukuran perusahaan terhadap nilai perusahaan.

Dari hasil pengujian tabel diatas nilai signifikansi untuk hasil pengujian hipoteis penelitian adalah sebesar 0,000 yang berarti lebih kecil dari 0,05, maka hasil uji F menunjukan bahwa ROA, DER dan ukuran perusahaan (LnSales) merupakan model regresi yang layak dan tepat dimana dari hasil semua variabel independen tersebut mempunyai pengaruh secara simultan terhadap variabel nilai perusahaan (Ln Hs). Maka hipotesis 6 diterima, artinya ROA, DER, dan ukuran perusahaan (ln Sales) berpengaruh secara simultan terhadap nilai perusahaan.

Uji Parsial (Uji T)

Tabel 10 Hasil Uji Parsial (Uji T)

\begin{tabular}{|c|c|c|c|c|c|c|}
\hline \multicolumn{2}{|c|}{ Mbdel } & \multicolumn{2}{|c|}{$\begin{array}{l}\text { Unstandardized } \\
\text { Coefficients }\end{array}$} & \begin{tabular}{|l|} 
Standardized \\
Coefficients \\
Beta \\
\end{tabular} & & Sig. \\
\hline \multirow{4}{*}{1} & (Constant) & 8.578 & .475 & & 18.060 & .000 \\
\hline & ROA & .007 & .010 & .025 & .648 & .517 \\
\hline & DER & .012 & .005 & .085 & 2.237 & .026 \\
\hline & $\begin{array}{l}\mathrm{L} \text { LSSALE } \\
\mathrm{S}\end{array}$ & -109 & .027 & -152 & -3.975 & .000 \\
\hline
\end{tabular}

Pengujian hipotesis 7: Pengaruh positif ROA terhadap nilai perusahaan

Berdasarkan hasil pengujian ROA terhadap nilai perusahaan (LnHS) menunjukan taraf signifikan sebesar 0,517 yang berarti lebih besar dari 0,05 dan nilai $\beta$ sebesar 0,007 , maka hipotesis 7 ditolak. Penelitian ini menunjukan tidak terdapat pengaruh positif ROA terhadap nilai perusahaan.

Pengujian hipotesis 8: Pengaruh negatif DER terhadap nilai perusahaan

Berdasarkan hasil pengujian DER terhadap nilai perusahaan (LnHS) menunjukan taraf signifikan sebesar 0,026 yang berarti lebih kecil dari 0,05 dan nilai $\beta$ sebesar 0,012, maka hipotesis 8 diterima. Penelitian ini menunjukan terdapat pengaruh negative DER terhadap nilai perusahaan.

Pengujian hipotesis 9: Pengaruh positif ukuran perusahaan terhadap nilai perusahaan.

Berdasarkan hasil pengujian ukuran perusahaan (lnSales) terhadap nilai perusahaan (LnHS) menunjukkan taraf signifikan sebesar 0,000 yang berarti lebih kecil dari 0,05 dan nilai $\beta$ sebesar 0,109 , maka hipotesis 9 diterima. Penelitian ini menunjukan terdapat pengaruh positif ukuran perusahaan terhadap nilai perusahaan.

Uji Koefisien Determinasi (R2)

Tabel 11 Hasil Uji Koefisien Determinasi (R2) Model Summary ${ }^{\circ}$

\begin{tabular}{|l|l|l|l|l|}
\hline Model & R & R Square & AdjustedR Square & $\begin{array}{l}\text { Std. Error of the } \\
\text { Estimate }\end{array}$ \\
\hline 1 & $.180^{2}$ & .032 & .028 & 1.77144 \\
\hline
\end{tabular}
a. Predictors: (Constant), LN_SALES, DER, ROA
b. Dependent Variable: In_hs

Pada tabel diatas menunjukan bahwa koefisien determinasi yang ditunjukan dari nilai R-Square sebesar 0,032 hal ini berarti 3,2\% variasi nilai perusahaan dapat dijelaskan oleh varian dari ketiga 
variabel independen yaitu ROA, DER, dan ukuran perusahaan. Sedangkan sisanya yaitu 96,8\% dijelaskan oleh faktor-faktor lain diluar variabel yang digunakan dalam penelitian ini.

Hasil Uji Analisis Regresi Binary Logistic

$$
\begin{gathered}
\text { Ln (odds) }=\mathrm{a}+\beta 1 \mathrm{ROA}+\beta 2 \mathrm{DER}+\beta 3 \mathrm{SIZE}+\mathrm{e} \\
\mathrm{Ln} \mathrm{PL}=1,761-0,012(\mathrm{ROA})-0,07(\mathrm{DER})-0,035(\mathrm{SIZE})+\mathrm{e} 1-\mathrm{PL}
\end{gathered}
$$

Persamaan diatas dapat dijelaskan sebagai berikut:

1. Konstanta sebesar 1,761 yang berarti perusahaan manufaktur melakukan praktik perataan laba dengan cara menaikan laba sebesar 1,761.

2. Koefisien regresi ROA negatif sebesar - 0,012 artinya setiap penurunan nilai ROA sebesar satu satuan sedangkan variabel lainnya dianggap konstan, maka akan menurunkan praktik perataan sebesar -0,012. Atau apabila ROA perusahaan naik 1\% maka besar peluang untuk melakukan perataan laba turun sebesar $1,2 \%$

3. Koefisien regresi DER negatif sebesar -0,071 artinya setiap penambahan nilai DER sebesar satu satuan sedangkan variabel lainnya dianggap konstan, maka akan menurunkan praktik perataan laba sebesar - 0,071. Atau apabila DER naik 1\% maka besar peluang untuk melakukan perataan laba sebesar $7,1 \%$

4. Koefisien regresi SIZE negatif sebesar -0,035 artinya setiap penurunan nilai SIZE sebesar satu satuan sedangkan variabel lainnya dianggap konstan, maka akan menurunkan praktik perataan laba sebesar -0,035. Atau apabila SIZE naik 1\% maka besar peluang untuk melakukan perataan laba turun sebesar $3,5 \%$.

\section{Hasil Uji Analisis Regresi Sederhana}

Analisis ini digunakan untuk menguji variabel intervening terhadap variabel dependen.

Berdasarkan tabel 7 diperoleh bentuk persamaan linear sebagai berikut:

$$
\begin{gathered}
\mathrm{NP}=\mathrm{a}+\beta 4 \mathrm{PL}+\mathrm{e} \\
\mathrm{NP}=6,705+0,020(\mathrm{PL})+\mathrm{e}
\end{gathered}
$$

Dari persamaan diatas, dapat diartikan bahwa:

1. Konstanta sebesar 6,705 artinya jika perataan laba sama dengan nol, maka nilai perusahaan sebesar 6,705 atau hal ini berarti bahwa jika perataan laba tidak mengalami peningkatan atau penurunan, maka nilai perusahaan sebesar nilai konstantanya yaitu 6,705 .

2. Koefisien perataan laba sebesar 0,020 artinya penambahan nilai perataan laba sebesar satu satuan sedangkan variabel lainnya dianggap konstan, maka akan menaikan nilai perusahaan sebesar 0,020. Atau apabila perataan laba naik 1\% maka besar peluang untuk menaikan nilai perusahaan adalah sebesar $2 \%$.

Hasil Uji Regresi Linear Berganda

Uji regresi uji regresi linear berganda digunakan untuk mengetahui arah dan besar pengaruh dari variabel independen. Bentuk persamaan linearnya adalah sebagai berikut:

$$
\begin{gathered}
\mathrm{NP}=\mathrm{a}+\beta 1 \mathrm{ROA}+\beta 2 \mathrm{DER}+\beta 3 \mathrm{size}^{+} \mathrm{e} \\
\mathrm{NP}=8,578+0.007 \mathrm{ROA}+0.012 \mathrm{DER}-0.109 \mathrm{SIZE}+\mathrm{e}
\end{gathered}
$$


Dari persamaan diatas, dapat diartikan bahwa:

1. Konstanta sebesar 8,578, artinya jika ROA, DER, dan Size sama dengan nol, maka nilai perusahaan sebesar 8,578 atau hal ini berarti bahwa jika ROA, DER, dan Size tidak mengalami peningkatan atau penurunan, maka nilai perusahaan sebesar nilai konstanta yaitu 8,578.

2. Koefisien ROA sebesar 0,025, artinya setiap penambahan nilai ROA sebesar satu satuan sedangkan variabel lainnya dianggap konstan, maka akan menaikan nilai perusahaan sebesar 0,025. Atau apabila ROA naik $1 \%$ maka nilai perusahaan naik sebesar $2,5 \%$.

3. Koefisien regresi DER 0,012 artinya setiap penambahan nilai DER sebesar satu satuan sedangkan variabel lainnya dianggap konstan, maka akan menaikan nilai perusahaan sebesar 1,2\%. Atau apabila DER naik $1 \%$ maka nilai perusahaan naik sebesar 1,2\%.

4. Koefisien regresi SIZE sebesar - 0,109 artinya setiap penambahan nilai Size sebesar satu satuan sedangkan variabel lainnya dianggap konstan, maka akan menurunkan nilai perusahaan sebesar - 0,109. Atau apabila Size naik 1\% maka besar peluang untuk menurunkan nilai perusahaan sebesar $10,9 \%$.

Pengujian Variabel intervening

Dari tabel UJi Wald dapat dilihat jika nilai a, b, c merupakan cerminan dari hubungan antara profitablitas (ROA), leverage (DER) dan ukuran perusahaan (LnSales) terhadap praktik perataan laba yang memiliki nilai wald sebesar a $($ ROA-PL $)=1,069 \mathrm{~b}($ DER-PL) $=3,731$ dan c (lnsales-PL) $=0,983$. Dari tabel uji parsial (uji T) dapat dilihat nilai d (PL-NP)yang merupakan cerminan dari hubungan antara perataan laba terhadap nilai perusahaan yang memiliki nilai beta masing-masing $\mathrm{d}$ $=0,005$. Dari tabel uji parsial pada hasil uji regresi berganda dapat dilihat nilai e, $\mathrm{f}$, dan $\mathrm{g}$ yang merupakan cerminan dari hubungan antara, ROA, DER, dan ukuran perusahaan terhadap nilai perusahaan yang memiliki nilai beta masing-masing e $(\mathrm{ROA}-\mathrm{NP})=0.025 \mathrm{f}($ DER-NP $)=0.085$ dan $\mathrm{g}(\mathrm{UP}-\mathrm{NP})=-0.152$.

Berikut ini adalah rincian dari hasil analisis jalur langsung dan hasil analisis jalur tidak langsung:

a. Proporsi ROA ke perataan laba

Pengaruh tidak langsung a x d = 1,069 x 0,005 =0,005345

Pengaruh langsung $=0,025$

Hal ini menunjukan bahwa koefisien (wald) pengaruh tidak langsung sebesar 0,005345. Angka ini lebih kecil dari koefisien ( $\beta$ ) pengaruh langsung yaitu 0,025. Kesimpulan yang dapat diambil bahwa perataan laba tidak memediasi pengaruh ROA terhadap nilai perusahaan.

b. Proporsi DER ke Perataan laba

Pengaruh tidak langsung b x d = 3,731 x 0,005 $=3,667573$

Pengaruh langsung $=0,085$

Hal ini menunjukan bahwa koefisien (wald) pengaruh tidak langsung sebesar 3,667573. Angka ini lebih besar dari koefisien ( $\beta$ ) pengaruh langsung yaitu 0,085. Kesimpulan yang dapat diambil bahwa perataan laba memediasi pengaruh DER terhadap nilai perusahaan.

c. Proporsi ukuran perusahaan ke perataan laba

Pengaruh tidak langsung $\mathrm{c} \times \mathrm{d}=0,983 \times 0,005=0,004915$

Pengaruh langsung $=-0,152$ 
Hal ini menunjukan bahwa koefisien (wald) pengaruh tidak langsung sebesar 0,004915. Angka ini lebih besar dari koefisien ( $\beta$ ) pengaruh langsung yaitu - 0,152. Kesimpulan yang dapat diambil bahwa perataan laba memediasi pengaruh ukuran perusahaan terhadap nilai perusahaan.

a $\mathrm{x} \mathrm{d}=1,069 \times 0,005=0,005345$

b x d $=3,731 \times 0,005=3,667573$

c x d $=0,983 \times 0,005=0,004915$

Syarat pengujian intervening yaitu:

$$
(a \times d)+(b x d)+(c x d)>(e+f+g) \text { "berfungsi sebagai variabel intervening }
$$

Dari hasil perhitungan statistik yang telah dilakukan menghasilkan nilai wald dan beta pada standardize coeficients untuk pengujian intervening. Hasil dari pengujian intervening yaitu:

$$
\begin{gathered}
(0,005345)+(3,667573)+(0,004915)>(0.025+0.085-0.152) \\
3,677833>-0.042 \text { "berfungsi sebagai variabel intervening” }
\end{gathered}
$$

Berdasarkan hasil data diatas dapat dilihat nilai $(a \mathrm{xd})+(\mathrm{b} x \mathrm{~d})+(\mathrm{c} x \mathrm{~d})>(\mathrm{e}+\mathrm{f}+\mathrm{g})$. Maka dapat disimpulkan bahwa peratan laba dalam penelitian ini berfungsi sebagai variabel intervening yang dapat memediasi antara variabel independen yaitu ROA,DER dan ukuran perusahaan dengan variabel dependen yaitu nilai perusahaan.

Temuan

a. Perataan laba dalam penelitian ini berfungsi sebagai variabel intervening yang dapat memediasi antara variabel independen (ROA, DER, Ukuran Perusahaan) dengan variabel dependen (nilai perusahaan). Perataan laba mempunyai nilai koefisien sebesar 0,020 pada uji pengaruh perataan laba terhadap nilai perusahaan yang artinya apabila perataan laba naik maka nilai perusahaan juga naik. Hal ini diduga akibat dari tindakan perataan laba yaitu nilai perusahaan dapat meningkat. Dengan tindakan perataan laba dapat meningkatkan kepercayaan investor akan kemampuan perusahaan untuk membiayai kegiatan operasional perusahaan sehingga dapat beroperasi secara optimal serta akan meningkatkan laba perusahaan. Dengan demikian investor akan merasa aman untuk berinvestasi dalam perusahaan tersebut dengan kepastian return yang akan didapatkan.Untuk manajemen tindakan perataan laba ini sangat menuntungkan bagi mereka, karena posisi manajer akan aman diperusahaan tersebut karena dianggap telah berprestasi dalam meningkatkan kinerja perusahaan, selain itu manajer juga akan mendapatkan bonus sesuai dengan perjanjian antara manajer dan principal hal ini sesuai bonus plan hypothesis.

b. Ditemukan bahwa perusahaan berusaha melakukan tindakan perataan laba dengan teknik increasing income melalui penjualan perusahaan. Hal ini diduga karena penjualan pada perusahaan manufaktur untuk periode 2014-2018 mengalami peningkatan. Adapun cara-cara yang dilakukan untuk melakukan tindakan perataan laba dengan teknik increasing income seperti dengan merubah teknik FOB dari sistem shipping point menjadi destination point, pada saat pembuatan faktur penjualan, misalnya pihak manajemen melakukan transaksi penjualan yang sebenarnya terjadi untuk periode yang akan datang tetapi pembuatan fakturnya dilakukan dan dilaporkan sebagai penjualan pada periode saat ini, dan pembuatan pesanan atau penjualan fiktif. Hal ini dilakukan dengan tujuan agar penghasilan perusahaan periode saat ini menjadi lebih tinggi dari yang seharusnya dilaporkan.

c. Penelitian ini menunjukan terdapat pengaruh negatif DER terhadap nilai perusahaan. Penggunaan hutang (leverage) dapat menurunkan nilai perusahaan. Hutang akan menambahkan beban tetap tanpa memperdulikan besarnya pendapatan. Semakin besar hutang semakin tinggi tingkat probabilitas kebangkrutan karena perusahaan tidak dapat membayar bunga dan 
pokoknya. Pihak manajemen harus memperhatikan penggunaan hutang, karena banyaknya hutang bisa menurunkan nilai perusahaan.Dengan tingginya rasio leverage menunjukan perusahaan tidak solvable, ini menunjukan respon negatif terhadap investor maka nilai perusahaan menurun.

d. Penelitian ini menunjukan tidak terdapat pengaruh positif ROA terhadap nilai perusahaan.Hal ini diduga karena perusahaan yang memiliki aset yang besar akan menanggung beban pajak yang lebih besar sehingga dapat menurunkan tingkat laba perusahaan. Dan dapat mengurangi pembagian deviden kepada investor sehingga investor tidak tertarik untuk membeli saham perusahaan tersebut.

\section{KESIMPULAN}

Berdasarkan hasil analisis dan pembahasan yang telah dikemukakan pada bab sebelumnya, maka dapat disimpulkan Hasil uji hipotesis 1: Pengaruh ROA, DER, dan ukuran perusahaan terhadap perataan laba secara simultan. Berdasarkan hasil pengujian variabel ROA, DER, dan ukuran perusahaan memiliki nilai signifikansi sebesar 0,070 yang berarti lebih besar dari tingkat signifikansi 0,05 maka dapat disimpulkan bahwa tidak terdapat pengaruh ROA, DER, dan ukuran perusahaan terhadap perataan laba secara simultan. Hal ini diduga karena ada kemungkinan investor cenderung mengabaikan pola perataan laba dan mengabaikan proses mendapatkan laba, investor hanya memperdulikan nilai yang dihasilkan dari praktik perataan laba. Hasil uji hipotesis 2 : Terdapat pengaruh positif ROA terhadap perataan laba. Berdasarkan hasil pengujian variabel ROA terhadap perataan laba diketahui bahwa variabel ROA menunjukkan taraf signifikansi sebesar 0,301 yang berarti lebih besar dari 0,05 dan nilai $\beta$ sebesar - 0,012 maka hipotesis 2 ditolak. Penelitian ini menunjukan bahwa tidak terdapat pengaruh positif ROA terhadap perataan laba. Hal ini diduga karena ada kemungkinan investor cenderung mengabaikan pola perataan laba dan mengabaikan proses mendapatkan laba, investor hanya memperdulikan nilai yang dihasilkan dari praktik perataan laba tersebut. Hasil uji hipotesis 3: Terdapat pengaruh positif DER terhadap perataan laba. Berdasarkan hasil pengujian DER terhadap perataan laba diketahui bahwa variabel DER menunjukan taraf signifikansi sebesar 0,053 yang berarti lebih besar dari 0,05 dan nilai $\beta$ sebesar -0,071, maka hipotesis 3 ditolak. Penelitian ini menunjukan tidak terdapat pengaruh positif DER terhadap perataan laba. Hasil uji hipotesis 4: Terdapat pengaruh positif ukuran perusahaan terhadap perataan laba. Berdasarkan hasil pengujian variabel ukuran perusahaan (LnSales) terhadap perataan laba diketahui bahwa variabel ukuran perusahaan (LnSales) menunjukkan taraf signifikansi sebesar 0,321 yang berarti lebih besar dari 0,05 dan nilai $\beta$ sebesar -0.035 maka hipotesis 3 ditolak. Penelitian ini menunjukan tidak terdapat pengaruh positif ukuran perusahaan (lnSales) terhadap perataan laba. Hasil uji hipotesis 5: Pengaruh negatif perataan laba terhadap nilai perusahaan. Berdasarkan hasil pengujian variabel Perataan Laba (PL) terhadap nilai perusahaan (LnHS) menunjukan taraf signifikan sebesar 0,901 yang berarti lebih besar dari 0,05 dan nilai $\beta$ sebesar 0,020 maka hipotesis 6 ditolak. Penelitian ini menunjukan tidak terdapat pengaruh negatif perataan laba terhadap nilai perusahaan. Hasil uji hipotesis 6: Pengaruh ROA, DER, dan ukuran perusahaan terhadap nilai perusahaan. Nilai signifikansi untuk hasil pengujian hipoteis penelitian adalah sebesar 0,000 yang berarti lebih kecil dari 0,05, maka hasil uji F menunjukan bahwa ROA, DER dan ukuran perusahaan (LnSales) merupakan model regresi yang layak dan tepat dimana dari hasil semua variabel independen tersebut mempunyai pengaruh secara simultan terhadap variabel nilai perusahaan ( $\mathrm{Ln} \mathrm{Hs}$ ). Maka hipotesis 5 diterima, artinya ROA, DER, dan ukuran perusahaan (ln Sales) berpengaruh secara simultan terhadap nilai perusahaan. Hasil uji hipotesis 7: Pengaruh positif ROA terhadap nilai perusahaan. Berdasarkan hasil pengujian ROA terhadap nilai perusahaan (LnHS) menunjukan taraf signifikan sebesar 0,517 yang berarti lebih besar dari 0,05 dan nilai $\beta$ sebesar 0,007 , maka hipotesis 7 ditolak. Penelitian ini menunjukan tidak terdapat pengaruh positif ROA terhadap nilai perusahaan. Hal ini diduga karena investor tidak memperhatikan pola perataan laba untuk mencapai target, investor hanya memperhatian nilai yang dihasilkan dari praktik perataan laba tersebut. Hasil uji hipotesis 8: Pengaruh negatif DER terhadap 
nilai perusahaan. Berdasarkan hasil pengujian DER terhadap nilai perusahaan (LnHS) menunjukan taraf signifikan sebesar 0,026 yang berarti lebih kecil dari 0,05 dan nilai $\beta$ sebesar 0,012, maka hipotesis 8 diterima. Penelitian ini menunjukan terdapat pengaruh negative DER terhadap nilai perusahaan. Hasil uji hipotesis 9: Pengaruh positif ukuran perusahaan terhadap nilai perusahaan. Berdasarkan hasil pengujian ukuran perusahaan (lnSales) terhadap nilai perusahaan (LnHS) menunjukan taraf signifikan sebesar 0,000 yang berarti lebih kecil dari 0,05 dan nilai $\beta$ sebesar 0,109 , maka hipotesis 9 diterima. Penelitian ini menunjukan terdapat pengaruh positif ukuran perusahaan terhadap nilai perusahaan.

Dalam hasil penelitian ini terdapat beberapa saran penelitian bagi Perusahaan perataan laba merupakan masalah yang kontroversial. Pada satu sisi, praktik perataan laba bersifat legal tanpa melanggar prinsip akuntansi berterima umum. Namun di sisi lain perataan laba ini dapat dikatakan perbuatan yang tidak etis dan tidak bermoral jika dilakukan dengan tujuan untuk mensejahterakan pihak tertentu karena kebutuhan hedonisme dalam dunia bisnis dapat dipenuhi dengan melakukan manajemen laba. Perilaku perataan laba pada perusahaan manufaktur yang dapat merugikan pihak tertentu sebenarnya dapat diminimalisir dengan diterapkannya 3 hal, yaitu pertama: Ketaatan terhadap prinsip kehati-hatian; kedua: pelaksanaan good corporate governance. GCG mengandung lima prinsip utama yaitu keterbukaan (transparency), akuntabilitas (accountability), tanggung jawab (responsibility), independensi (independency) serta kewajaran (fairness), dan diciptakan untuk dapat melindungi kepentingan semua pihak yang berkepentingan (stakeholder). Ketiga: Dalam mengatasi perataan laba pemilik harus mencermati perilaku manajemen dengan memberikan biaya pengawasan atau montoring untuk mengawasi kegiatan operasional manajemen perusahaan. Bagi calon investor dan kreditur perlu berhati-hati dalam menentukan keputusan untuk berinvestasi dan pemberian dana serta memastikan tingkat kualitas laporan keuangan perusahaan tersebut. Bagi peneliti selanjutnya dapat mengembangkan sektor industri lain dan menambah pengujian faktorfaktor yang mempengaruhi perataan laba serta nilai perusahaan.

\section{DAFTAR PUSTAKA}

Albrecht, W. D. \& Richardson, F. M. (1990). IncomeSmoothing by Economy Sector. Journal of Business Finance\& Accounting, 17 (5), 713- 730.

Budiasih, I. (2009). Faktor-Faktor yang Mempengaruhi Praktik Perataan Laba. Jurnal Akuntansi dan Bisnis, 4 (1).

Fatmawati \& Djajanti, A. (2015). Pengaruh Ukuran Perusahaan, Profitabilitas, dan Financial Leverage terhadap Praktik Perataan Laba pada Perusahaan Manufaktur yang Terdaftar di Bursa Efek Indonesia. Kelola, 2 (3)

Ghozali. (2006). Ekonometrika Teori dan Aplikasi SPSS 17, Semarang : Universitas Diponegoro.

Hanlianto, P. D. (2013). Pengaruh Pertumbuhan Penjualan Profitabilitas dan Likuiditas Terhadap Kebijakan Hutang Pada Perusahaan Retail Yang Terdaftar di Bursa Efek Indinesia Periode 2007-2009, Skripsi, Universitas Esa Unggul, Jakarta

Hendrikson, E. S., \& Van Brenda, M. F. (2000). Teori Akunting. Jilid Satu. Batam. Indonesia Fama, E.F. (1980). Agency problems and the theory of the firm. Journal of political economy 88 (2), 289-307

Salno, H. M. \& Z. Baridwan. (2000). Analisis Perataan Penghasilan (Income Smoothing): Faktor- Faktor yang Mempengaruhi dan Kaitannya dengan Kinerja Saham Perusahaan Publik di Indonesia. Jurnal Riset Akuntansi Indonesia, 3(1), 17-34.

Suharli, M. (2006). Studi Empiris Terhadap Faktor yang Mempengaruhi Nilai Perusahaan Pada Perusahaan Go Public di Indonesia. Jurnal Maksi, 6 (1), 23-41 